Neves, A.A.F., Sales, V.C.W., Cardoso, D.R., Barros Neto, J.P. (2018). "Guidelines for Public Project Design Development." In: Proc. $26^{\text {th }}$ Annual Conference of the International. Group for Lean Construction (IGLC), González, V.A. (ed.), Chennai, India, pp. 560-570. DOI: doi.org/10.24928/2018/0437. Available at: www.iglc.net.

\title{
GUIDELINES FOR PUBLIC PROJECT DESIGN DEVELOPMENT
}

\author{
Antônio Arthur Fortaleza Neves', Vitor Cruz Werton Sales ${ }^{2}$, Daniel Ribeiro \\ Cardoso $^{3}$, and José de Paula Barros Neto ${ }^{4}$
}

\begin{abstract}
The project development and budgets (PDB) process of public enterprises is carried out in a piecemeal fashion by stakeholders. This situation contributes to several inadequacies of constructions, mainly related to costs and deadlines. The present work aims to propose guidelines to the PDB process of public enterprises based on the Target Value Design (TVD) process and the identification of practices used in the investigated institutions. The study was carried out in four public institutions in Brazil, through qualitative research. The study approach was subdivided into three stages: process investigation based on the TVD; elaboration of guidelines for the process; and evaluation of these guidelines. As a result, the paper presents 13 guidelines distributed in three axes: project budgeting process; planning and process control; and BIM process. The present study demonstrates feasibility in the guidelines application, as evaluated by the investigated ones, thus allowing them to be used to construct integrated PDB processes models.
\end{abstract}

\section{KEYWORDS}

Integration, Process, Target Value Design (TVD), Project Development Process.

\section{INTRODUCTION}

In Brazil, public enterprises are contracted through public bidding, which according to Law 8.666 / 1993 (Brazil 1993) allows the bidding to be carried out from a basic project, which is classified as a "set of necessary elements and sufficient, with an adequate level of precision, to characterize the work or service, ... object of the bid. "This brief description of basic design does not make clear the requirement for an executive-level project.

Research on public works projects reports that project failures and changes in projects during the project are pointed out as the main causes that impact on cost increases of works (Santos; Starling; Andery 2015).

1 Researcher of the GERCON, Federal University of Ceará (UFC), Brazil, +55 85987452506 , arthur@artificearquitetura.com.br

2 Researcher of the GERCON, Federal University of Ceará (UFC), Brazil, +55 85996845526 , vitorwerton@hotmail.com

3 Professor, Federal University of Ceará (UFC), Brazil, +55 85 33669607, daniel.br@ mac.com

4 Professor, Federal University of Ceará (UFC), Brazil, +55 85 33669607, barrosneto@ gercon.ufc.br 
In another study carried out by synthesizing data from the literature, it was verified that $47 \%$ of the inadequacies of deviations from costs and deadlines in construction projects are directly related to the following categories: management (lack of planning and control of costs in the pre and post-contract - incorrect estimate of material - among others); project and documentation (defects, errors and omissions in the project alteration of the project - delay in the elaboration and approval of the project - among others) (Muianga; Granja; Ruiz 2015).

As it is observed in the literature, the architectural and engineering (AE) projects are pointed like preponderant items for assertiveness in the anticipates costs in budgets of real estate ventures. This context is the main justification for the present study.

From the discussion of inadequacies in public constructions, some collaborative aspects in the process of developing projects and budgets are related, such as: integration of technical teams; improvement in process description; use of BIM; anticipation of actions in the project process; improvement in the computerized communication system (Neves et al. 2017).

The proposal for the development of the study is characterized by the investigation process of the context of project development in public enterprises, through case studies, using theoretical process Target Value Design (TVD).

Seeking to frame the research problem, an essential question arises based on the presented aspects: How to improve the projects development process of projects of public enterprises? As objective, the present study aims to elaborate guidelines for the participants in the development of projects of public enterprises.

\section{TARGET VALUE DESIGN}

The discussion of value in this process is defended by lean thinking, which is based on the principles of lean construction proposed by Koskela (1992), among which it is possible to highlight: increasing the value of the product / service by systematically considering the requirements of customers; and focus on overall process control.

The TVD is based on lean thinking and uses 17 theoretical elements that relate stages of the development process of $\mathrm{AE}$ projects with the objective of guarantee the value established by the client. The process considers the participation of the customer (owner or responsible) and the suppliers in the stages of development of real estate products, besides emphasizing the importance of budget cycles to guarantee the established cost (Ballard 2011).

TVD aims to have a construction done within a desired budget, according to a detailed estimate. For this, value, cost, schedule and constructability are established as basic components of the project criteria (Forbes; Ahmed 2011).

The TVD presents fundamental points such as: the client's decision about financing the undertaking; the determination of the total cost; integration between teams of designers, suppliers and customers; and routine budgets throughout the process. (Ballard 2011) 
In Brazil the approach to TVD is still limited, and it is necessary to diffuse its elements, thus enabling the process of knowledge about a rigorous management method for the development of products in civil construction, involving developers, architects, engineers, builders and suppliers (Oliva; Melo; Granja 2015)

The Last Planner System (LPS) and Building Information Modeling (BIM) are considered catalysts for the TVD process and are not mandatory. However, it is emphasized that, in order to achieve higher levels of collaboration, these catalysts become mandatory (Oliva; Granja 2015).

Target Cost (TC) has a strong relationship with TVD, considering that the two methods aim to reduce costs, ensuring quality, reliability among other attributes, thus generating value for customers (Miron; Kaushik; Koskela 2015). Oliva et al. (2016) suggest that TVD should be reviewed in the light of the original theory of TC to better adapt to the new applications to be carried out in real estate projects.

The benefits of TC application increase over time as the company gains in productive efficiency and increases its cost sensitivity. In addition, it strengthens the method of collaborative work (Jacomit; Granja 2011). The main functions, or construction systems, can be adjusted based on the TC, through the identification of ideas for cost reduction through a systematic process of balance between cost and performance (Ruiz; Granja; Kowaltowski 2012).

The LPS can be applied in the design process, aiming to plan and control the products obtained through the strategic, tactical and operational levels, thus making possible the increase of the reliability of the process through the completion of tasks. In this way, it composes levels of planning based on the commitment of the participants (Ballard; Howell 1998; Khan; Tzortzopoulos 2014).

In short, a project process can evolve from new methods and processes, aimed at its development in an integrated way and stimulating the autonomy and participation of stakeholders, prioritizing the simultaneity of the projects, as well as the systematization and documentation of the process (Fabricio 2002; Barros Neto; Nobre 2009).

\section{METHOD}

The present research is classified as qualitative, being one of the objectives of this type of research the performance in social issues (Poupart et al. 2008). The research strategy adopted was the case study, when the phenomenon to be studied is contemporary, and it happens in a context of real situation (Yin 2001).

As a delimitation of the research object, 04 public institutions were studied, being composed by sectors of project development, budgets and construction supervision. The research covers the linear chain of activities that are components of the public enterprise production system, which was subdivided into three stages: investigation of the process in the light of TVD; elaboration of guidelines for the process; and evaluation of these guidelines. 


\section{INVESTIGATION OF THE PROCESS IN THE LIGHT OF TVD}

In the present study, TVD is considered a fundamental reference, therefore, previous bibliographic research was performed according to Neves et al. (2016). The systemic search on the subject was carried out with the aim of identifying the works with greater representativity and seminal authors. Based on this search, the data collection instrument was elaborated and had as theoretical foundation the 17 elements proposed by Ballard (2011), as well as the TVD catalysts according to Oliva and Granja (2015). This instrument was subdivided into 03 parts: basic project development (26 questions); TVD catalysts (03 questions); and respondents' contributions (03 questions).

The selection of the case studies was carried out from the outline of public institutions that maintained common organizational structures, such as: AE project development and budgets sector; and construction supervision sector. Therefore, 04 public institutions were studied, involving a total of 17 participants: 03 clients; 05 managers; 03 designers (architects and engineers); 03 budgeteers; 03 works inspectors ${ }^{5}$.

Since this is a qualitative study, a delimitation is necessary in cases that were willing to contribute to the present study. Therefore, contact was established with the participating institutions. The sectors studied are responsible for the development of projects, budgets and construction bids. In this last case, each institution has only one architecture and engineering sector. Institutions use similar production procedures.

The institutions investigated work in the public segment in the states of Ceara and Santa Catarina, being denominated: Institution A; Institution B; Institution C; and Institution D

After data collection, the interviews were transcribed with the purpose of allowing rereading, supporting the process of data organization and subsequent analysis. This phase was performed according to a protocol elaborated from Bardin (1977), which was structured according to the following sequence: preliminary reading; selection of specific texts; segregation of text samples; construction of coded reference; and data correlation. The NVivo software was used for data analysis. In this way it was possible to understand the projects development process of public enterprises, considering all phases involved.

\section{ELABORATION OF GUIDELINES FOR THE PROCESS}

Based on the previous stage, it was possible to elaborate the guidelines for the public enterprises projects development, these being structured from TVD, through three axes: process of projects and budgets; planning and process control; and use of BIM.

5 According to Law 8.666 / 1993 (BRAZIL, 1993), in public institutions there is a restriction of external participation to the institution, making it impossible for the builder to participate in the process. Thus, it is necessary to adapt the TVD to public institutions. Therefore, for this study, it was possible to adapt the participation of the constructor, which was replaced by the "Working Inspector", participant responsible for monitoring and inspecting works of the institution. The works inspector is considered a technical servant who has the knowledge and experience in relation to the works. It is important to remember that this adaptation is only possible in public institutions that have a complete technical team to develop projects. 
Antônio Arthur Fortaleza Neves, Vitor Cruz Werton Sales, Daniel Ribeiro Cardoso

and José de Paula Barros Neto

\section{EVALUATION OF THE GUIDELINES FOR THE PDB PROCESS}

The elaborated guidelines were submitted to the evaluation in one of the studied institutions, each one being evaluated under three aspects: feasibility; expectation of application; and conflict with Law 8.666 / 1993.

Institution A was chosen for the evaluation by concentrating the largest amount of data collected. The evaluation model was collected through a meeting with members of the institution.

The evaluation process was conducted by the researchers through rounds of discussion, in each round being collected the opinions of the servers. At the end of the meeting, answer sheets were collected, drawn up based on the evaluation aspects, properly completed by the participants.

\section{RESULTS}

\section{GUIDELINES FOR THE PDB PROCESS}

The need to adopt integrated project development processes is raised by the servers themselves, as well as planning and controlling activities, and adopting new technologies. Thus, based on the aspects raised in the present study, the guidelines were elaborated and based theoretically on the works of Ballard (2011) and Oliva and Granja (2015), relating the TVD elements and their catalysts to the gaps observed in the study. In this way, the guidelines were distributed according to the following axes: process of projects and budgets; planning and process control; and use of BIM.

\section{GUIDELINES ON PROJECT AND BUDGET PROCESS}

It is observed that "budget error" and "project error" stand out as the main causes pointed by the interviewees for the inadequacies in public works related to costs. Some of the respondents reported that budget errors often happen because of project errors.

In Institution B, the participant "WI" demonstrated not to know many of the aspects pertinent to the process reported by the participants in the technical area, "designer" and "budgeteer". In general, the WI only has effective participation in the post-bidding phase, that is, after the effective contracting of the company contracted to carry out the work.

From the results, it is evidenced that the institutions do not recognize the Definition of Financial Resource (DFR) phase as a strategic process, because, according to the reports, the determination of the cost of the enterprise is made by the history of works previously carried out by the institutions themselves.

This decision on the cost of the project is established as the guiding parameter of the PDB, which only knows the cost of the work at the end of the project development. For institutions, this requires adaptation to the allocated resource, or requires that the project be adjusted to the pre-determined resource.

The DFR process considers only the participation of the architect and does not consider the involvement of engineering designers, budgets and construction supervisors. In this way, the process eliminates the possibility of discussion among participants with 
experience in other areas of engineering, either for the definition of construction costs or to discuss the problems generated by system specifications inconsistent with the projects and only discovered during the construction.

The fact that there is no documentary process in the DFR phase weakens the later phase, since it allows the project to be modified during the development process to fit the needs of the client.

Table 1 presents the consolidation of the guidelines on the project process and budgets.

Table 1: Guidelines on the Project Process and Budgets

\section{Guidelines - Project and Budget Process}

1 Implement a process of integrated development of projects and budgets, also considering the DFR phase, among the participating members, these being: clients; managers; architects; design engineers; budgeting; and WI. This action must be preceded by selection of participants and duly registered. It is important that the technical team share the same physical space in their work routine.

2 Standardize and systematize the DFR and PDB processes, as well as the documentation pertinent to these processes.

3 Conduct presentation to participating members about the needs of customers as well as the benefits planned for the venture. This action should also include guidance on possible cost constraints and deadlines of the enterprise.

4 Define the costs for execution and operation of the project still in the DFR phase.

5 Use creative costing-goal process tools to optimize and reduce costs.

6 Develop budget and work schedule in advance, starting at the DFR stage and subsequently developed during the project and budget process.

7 Establish cost goals and schedules for each project discipline. This action must be carried out through updates of estimates by area throughout the project and budget process, and it is necessary to evaluate the predetermined targets.

\section{GUIDELINES ON PLANNING AND CONTROL OF THE PROCESS}

According to the research participants, there is no long- and medium-term planning for the project and budget activities, but two of the interviewees reported that there is a computerized work routine control system. In this system the servers supply the shortterm schedules. This system was presented to the researcher, as well as the access link was made available as a form of supporting evidence.

Other reports indicate that short deadlines for process development can lead to project errors, as project changes throughout the process or work can lead to higher project costs.

Table 2 presents the consolidation of the guidelines on planning and process control. 
Antônio Arthur Fortaleza Neves, Vitor Cruz Werton Sales, Daniel Ribeiro Cardoso

and José de Paula Barros Neto

Table 2: Planning and Process Control Guidelines

Guidelines - Planning and Process Control

8 Implement planning and control system in the projects and budgets development process considering: long-term planning; medium-term planning; and short-term planning.

9 Program the short-term planning in an integrated way, considering the participation of the management and operational teams, so that the planned activities are controlled, as well as exist the feedback of the long and medium planning, aiming the learning and evolution of the system.

\section{GUIDELINES ON THE USE OF BIM}

It appears that the use of BIM, in part of the institutions, still does not constitute a policy. However, the isolated actions by some architects in working with BIM reflect the innovative stance of these servers.

The participant of Institution D reports that the conceptual project in the FS phase is carried out through BIM modeling of the preliminary study in the LOD $^{6}-100$, as well as the documentary process of approval of the FS is performed, being in two formats: the analysis matrix, recorded in printed process; and BIM model, registered in BCF (BIM Collaboration Format), that can be visualized in other tools of software directed towards the client.

The participation of the "budgeteers" in the FS phase in BIM does not exist, according to the participant of Institution D, who affirms that there is no such function in the sector, which is assumed by the engineer or architect. The same one affirms that, with the use of BIM, there is a clash between the quantitative generated in the model and the budget base presented in the official tables, being this a limitation generated.

According to the "Designer" of Institution A, the implementation of BIM in the institution is developed through three axes: 1) pilot project in joint with the architecture and budget teams; 2) capacity activities through training, with the objective of bringing professionals closer to the BIM methodology; 3) implementation of BIM process in the projects and budgets development.

The participants reported some possible future contributions with the use of BIM, these being: reduce project production time; reduce design errors; because it considers an efficient work tool, soon there is an increase in the information confidence; reduce divergences between project and budget; improve the process in a general way; facilitate the projects and budgets preparation; improved level of detail.

Table 3 presents the consolidation of the guidelines on the BIM use.

6 LOD (Level of Development) is defined as a classification for elements modeled in BIM, facilitating communication between project participants. LOD 100: elements are not geometric representations. LOD 200: elements are geometric representations, considered components, but they present approximate information. 
Table 3: Guidelines on BIM use

Guidelines - BIM use
$10 \begin{aligned} & \text { Select a key team of servers, architects and engineers, for training and qualification in } \\ & \text { BIM, aiming the development of pilot model. The main purpose of said model is to provide } \\ & \text { data for structuring process standardization in BIM. }\end{aligned}$
11 Prepare standard specifications to meet the technical information needs of BIM. This
booklet should consider the complete chain of information on the components, elements
and building systems commonly used by the institution.
12 Establish work cost parameterization based on BIM models from the LOD 100 and LOD
200 classification, considering that these classifications are pertinent to the financial
resource definition phase, being characterized as conceptual studies or preliminary
studies.
13 Adapt the function of employees, architects and engineers to the new working paradigm
established by BIM, considering that the models provide the quantitative from the
parameterized geometric basis. This adaptation is directly correlated with the budgeteer,
which should contribute to the process assuming a new role. In the latter case, the
learning process is the function adjustments basis.

It is important to note that a final guideline was proposed for the present study, but this was eliminated after the evaluation, as presented in figure 1. The aforementioned guideline was listed as "14" and has the following purpose: "To structure reference base of composite costs in BIM, with the purpose of contributing to future adaptations in the official tables of costs and indices of civil construction".

\section{GUIDELINES EVALUATION}

Figure 1 presents the consolidated result of the guidelines evaluation carried out by the participating members of Institution A.

\begin{tabular}{|c|c|c|c|c|}
\hline Guideline & Is it viable? & Application Expectation & Conflict with Law 8,666/1993 & Comments \\
\hline 1 & Yes & 2 Years & No & 1 \\
\hline 2 & Yes & 6 Months & No & 2 \\
\hline 3 & Yes & 2 Years & No & 3 \\
\hline 4 & Yes & 2 Years & No & 4 \\
\hline 5 & Yes & 2 Years & No & $05^{*}$ \\
\hline 6 & Yes & 2 Years & No & 6 \\
\hline 7 & Yes & Over 2 years & No & $07^{*}$ \\
\hline 8 & Yes & 1 Year & No & $08^{*}$ \\
\hline 9 & Yes & 1 Year & No & $09^{*}$ \\
\hline 10 & Yes & 2 Years & No & 10 \\
\hline 11 & Yes & 2 Years & No & 11 \\
\hline 12 & Yes & 2 Years & No & $12^{*}$ \\
\hline 13 & Yes & Over 2 years & No & 13 \\
\hline 14 & No & - & - & $14^{* *}$ \\
\hline
\end{tabular}

Figure 1: Guidelines Evaluation 
Following the observations made by the participants during the evaluation: 01- It is an extreme urgency guideline for projects carried out by internal teams, and can be implemented more easily; 02- Important and necessary guideline, especially in public service and legal demands, however, will require time and dedication from the team; 03It should be included as a preliminary project step (needs program / feasibility studies) and duly registered as part of the work routine, avoiding future and recurring changes; 04- It is not clear if sufficient information will be available to elucidate execution and operation costs in an initial project stage (financial resource definition). Only if you work with building standards; 06- It depends on the level of budget detail / construction schedule; 10- Process in progress, but linked directly to guideline 2, for long-term implementation; 11- Process in progress, however, it is linked directly to guideline 2, for long-term implementation. The especifications would be the end result of the process, being desirable for the whole institution, not just for the BIM implementation. Thus, it would allow greater integration between project, budget, process control, transparency and efficiency; 14- Impracticable. It demands a great effort on the team commitment. It is believed that it will be a market transformation through the culture change with the use of BIM.

Some points were raised during the evaluation, mainly regarding doubts about the implementation or application of the guidelines in question, according to the observations: $05 ; 07 ; 08 ; 09 ; 12$; and 13 . However, it is considered that only through a model implementation process, based on the guidelines, would these questions be elucidated.

\section{CONCLUSIONS}

This study aims to propose guidelines to the participants in the project development of public enterprises, considering that the said process shows weakness in the preliminary definition of costs, which begins to reflect in the whole subsequent process. The research contributes to the discussion about aspects that directly affect the quality of projects developed in public institutions in Brazil.

Public institutions commonly estimate the cost of new projects by considering the cost history of similar existing buildings, or use information based on the Basic Unit Cost (BUC), a cost indicator for the construction industry in Brazil. Therefore, this integration proposal is not only a theoretical discussion, as observed in the results of the research, but also reflects a need pointed out by the servers investigated.

\section{REFERENCES}

Ballard, G. Target Value Design: current benchmark. Lean Construction Journal, v. 6, n. 1, p. 79-84, 2011.

Ballard, G; Howell, G. Shielding production: an essential step in production control. Journal of Construction Engineering and Management, New York, v. 124, n. 1, p. 1824. Jan. 1998.

Bardin, Laurence. Análise de conteúdo. Lisboa: Edições 70, p. 225, 1977. 
Barros Neto, J. P.; NOBRE, J. A. P. O processo de desenvolvimento de produto imobiliário: estudo exploratório em uma incorporadora. Produção, v. 19, n.1, p. 87104, 2009.

Brasil. Decreto-lei no 8.666, de 21 de junho de 1993, que institui normas para licitações e contratos da Administração Pública e dá outras providências. Diário Oficial do Estado de São Paulo, São Paulo, 22 de junho de 1993.

Fabricio, Márcio Minto. Projeto simultâneo na construção de edifícios. 2002. 350 f. Thesis (Doctorate Degree) - USP, São Paulo, 2002.

Forbes, L.H. \& Ahmed, S.M. 2011, Modern Construction: Lean Project Delivery and Integrated Practices. Boca Raton, FL: CRC Press Inc.

Jacomit, A.M.; Granja, A.D. An investigation into the adoption of target costing on Brazilian public social housing projects. Architectural Engineering and Design Management, 7(2), 113-127, 2011.

Khan, S. \& Tzortzopoulos, P. 2014, Effects of the Interactions Between LPS and BIM on Workflow in Two Building Design Projects In:, Kalsaas, B.T., Koskela, L. \& Saurin, T.A., Proc. 22nd Annual Conference of the International Group for Lean Construction. Oslo, Norway, 25-27 Jun 2014. pp 933-944

Koskela, L. Application of the New Production philosophy to Construction. Technical Report n 72. Center for Integrated Facility Engineering. Department of Civil Engineering. Stanford University, 1992, 72 p.

Muianga, E. A. D.; Granja, A. D.; Ruiz, J. de A. Desvios de custos e prazos em empreendimentos da construção civil: categorização e fatores de influência. Ambiente Construído, Porto Alegre, v. 15, n. 1, p. 79-97, jan./mar. 2015.

Neves, A. A. F.; Sales, V. C. W.; Cardoso, D. R.; Sousa, D. S. V.; Barros Neto, J. P. Análise dos aspectos colaborativos na gestão de projetos e obras de empreendimentos públicos. In: Simpósio Brasileiro de Gestão e Economia da Construção, 10., 2017, Fortaleza. Anais... Porto Alegre: ANTAC, 2017.

Neves, A. A. F.; Saraiva, R. L. P.; Comelli, M. L.; Sousa, D. S. V.; Barros Neto, J. P. Pesquisa bibliométrica sobre Target Value Design. In: ENCONTRO NACIONAL DE TECNOLOGIA DO AMBIENTE CONSTRUÍDO, 16., 2016, São Paulo. Anais... Porto Alegre: ANTAC, 2016.

Oliva, C. A.; Granja, A. D. Proposta para adoção do Target Value Design (TVD) na gestão do processo de projeto de empreendimentos imobiliários. Ambiente Construído, Porto Alegre,v. 15, n. 4, p. 131-147, out./dez. 2015.

Oliva, C.A., Granja, A.D., Ballard, G., Melo, R.S.S. 2016. "Assessing Suitability of Target Value Design Adoption for Real Estate Developers in Brazil." In: Proc. 24th Ann. Conf. of the Int'1. Group for Lean Construction, Boston, MA, USA, sect.4 pp. 93-102.

Oliva, C. A.; Melo, R. S. S.; Granja, A. D. Target Value Design na gestão do processo de projeto por meio de simulação: difusão de conceitos e reflexões teóricas. PARC Pesquisa em Arquitetura e Construção, v. 6, n. 1, p. 4-15, 2015.

Poupart, J. et al. A pesquisa qualitativa: enfoques epistemológicos e metodológicos. Vozes, 2008. 
Ruiz, J. A.; Granja, A. D.; Kowaltowski, D. C. K. Gerenciamento de valor em EHIS: uma proposta para reavaliação de custos com base na entrega de valor aos usuários finais. In: ENCONTRO NACIONAL DE TECNOLOGIA DO AMBIENTE CONSTRUÍDO, 14., 2012, Juiz de Fora. Anais... Porto Alegre: ANTAC, 2012.

Santos, H. De P.; Starling, C. M. D.; Andery, P. R. P. Um estudo sobre as causas de aumentos de custos e de prazos em obras de edificações públicas municipais. Ambiente Construído, Porto Alegre, v. 15, n. 4, p. 225-242, out./dez. 2015.

Yin, R. K. Estudo de caso: planejamento e métodos. 2 ed. Porto Alegre: Bookman, 2001. 